\title{
CORRECTION
}

\section{Correction to: Can COVID-19 Increase the Risk of Herpes Zoster? A Narrative Review}

\author{
Javier Diez-Domingo (D) - Raunak Parikh (1) - Amit B. Bhavsar (1) · \\ Elisa Cisneros (1) - Natalia McCormick (1) - Nicolas Lecrenier (1)
}

Published online: June 15, 2021

(c) The Author(s) 2021

Correction to: Dermatol Ther (Heidelb)

https://doi.org/10.1007/s13555-021-00549-1

Authors would like to correct the errors in their publication.

1. On the Results and Discussion section, Description of $\mathrm{HZ}$ cases in patients with COVID-19, subsection Demographic and Co-Morbid conditions:

The original article can be found online at https://doi. org/10.1007/s13555-021-00549-1.

J. Diez-Domingo

FISABIO-Public Health, Valencia, Spain

e-mail: javier.diez@fisabio.es

R. Parikh $(\bowtie) \cdot$ A. B. Bhavsar

GSK, Wavre, Belgium

e-mail: raunak.p.parikh@gsk.com

\begin{abstract}
A. B. Bhavsar
e-mail: amit.b.bhavsar@gsk.com

E. Cisneros - N. McCormick

GSK, Madrid, SpainE. Cisneros

e-mail: elisa.x.cisneros@gsk.com
\end{abstract}

N. McCormick

e-mail: natalia.x.mccormick@gsk.com

N. Lecrenier

GSK, Rixensart, Belgium

e-mail: nicolas.lecrenier@gsk.com
There were cases with known risk factors for $\mathrm{HZ}$, which included age over 50 years of age $(\mathrm{n}=18)$,

The correct number is 19 .

2. Change of references 4 and 27:

- Correct reference 4 is: Wang B, Guo S, Yao Y, Li Y, Zhang G (2020) Dermatologists may need to pay more attention to herpes zoster during the pandemic of COVID-19. Infect Dis. https://doi.org/ 10.1080/23744235.2020.1797158

- Correct reference 27 is: Dworkin RH, et al. Clinical Infectious Diseases 2007; 44:S1-26

The original article has been corrected.

Open Access. This article is licensed under a Creative Commons Attribution-NonCommercial 4.0 International License, which permits any non-commercial use, sharing, adaptation, distribution and reproduction in any medium or format, as long as you give appropriate credit to the original author(s) and the source, provide a link to the Creative Commons licence, and indicate if changes were made. The images or other third party material in this article are included in the article's Creative Commons licence, unless indicated otherwise in a credit line to the material. If material is not included in the article's Creative Commons licence and 
your intended use is not permitted by statutory regulation or exceeds the permitted use, you will need to obtain permission directly from the copyright holder. To view a copy of this licence, visit http://creativecommons.org/licenses/bync/4.0/. 